\title{
Stage IA Vulvar Carcinoma AJCC v6
}

National Cancer Institute

\section{Source}

National Cancer Institute. Stage IA Vulvar Carcinoma A/CC v6. NCI Thesaurus. Code C6328.

Stage IA includes: Tia, N0, M0. T1a: Tumor confined to the vulva or vulva and perineum, $2 \mathrm{~cm}$ or less in greatest dimension, and with stromal invasion no greater than $1 \mathrm{~mm}$. NO: No regional lymph node metastasis. M0: No distant metastasis. (AJCC 6th ed.) - 2003 